\title{
PHYSIOLOGICAL EFFECTS OF THE BROWN SEAWEED (ASCOPHYLLUM NODOSUM) AND HUMIC SUBSTANCES ON PLANT GROWTH, ENZYME ACTIVITIES OF CERTAIN PEPPER PLANTS GROWN UNDER SALT STRESS
}

\author{
Mahmut Yildiztekin, ${ }^{1}$ * Atilla Levent Tuna ${ }^{2}$ and Cengiz Kaya ${ }^{3}$ \\ ${ }^{1}$ Department of Herbal and Animal Production, Koycegiz Vocational School, \\ Muğla Sttkı Kocman University, Köyceğiz-48800, Muğla, Turkey \\ ${ }^{2}$ Department of Biology, Faculty of Science, Muğla Sitkı Kocman University, \\ Muğla-48000, Muğla, Turkey \\ ${ }^{3}$ Department of Soil Science and Plant Nutrition, Faculty of Agriculture, Harran University, \\ Şanlıurfa-63000, Turkey
}

(Received: December 09, 2017; accepted: April 26, 2018)

\begin{abstract}
This study was aimed to examine the effects of seaweed extract (SW) and humic acid on the fruit yield, dry weight (DW\%), protein, proline, lipid peroxidation (LPO) and antioxidative enzyme activity of pepper plants (Capsicum annuum L.) grown under saline conditions $(100 \mathrm{mM})$. The obtained results indicated that salinity stress affected deleteriously plant growth and all other parameters. Besides, the treatment of seaweed (SW) and humic acid (HA) improved vegetative growth in the plant at all concentration levels applied under salinity conditions. Leaf fresh and dry weight was increased by all SW and HA applications in salinity stressed plant compared to those of control. Furthermore, there was a significant improvement in antioxidant enzyme activity, such as superoxide dismutase (SOD), peroxidase (POD), catalase (CAT) activities in the plant under salt stress and treated with SW and HA compounds. It suggests that seaweed and humic acid can enhance salt stress tolerance and leads to conservation of pepper plant against oxidative stress.
\end{abstract}

Keywords: Capsicum annuum L. - salt stress - antioxidative enzymes - seaweed - humic acid

\section{INTRODUCTION}

Salinity is one of the most critical issues in these regions which regions for agricultural production. Almost 9.5 billion hectare of the earth's land is saline, apart from large areas of lesser salinized soil in cultivation sites [29]. Environmental stresses as saltiness and aridness diminish growth and agricultural fertility more than other factors [1]. The detrimental impacts of chlorinity on plant growth are related to the insufficient osmotic capacity of soil dispersion, nutritional unbalance, particular ion impact, or else a component of these parameters [4]. The salinity of soil is also turning into a main agricultural challenge during the whole of vegetable growing areas in Turkey. However, some reports show that applying with natural products like humic

\footnotetext{
*Corresponding author; e-mail address: mahmutyildiztekin@mu.edu.tr
} 
acids and seaweed, enhances salinity endurance of crops probably by hormonal regulation of plant defense systems against oxidative stress.

Humic acids, the primary acid extractable compound of humic materials, composed of a hydrophobic theory of aromatic circles bounded by elastic carbon chains, with alcohol, amide, amine phenol, carbonyl and carboxylic functional group [15], improve enzymes activity and stimulate stress resistance [14]. Besides, Sargassum polycystum known as brown seaweed algae that are mostly found in tropical regions has essential economic value because of its uses as conventional medicine, animal forage, and chemical products in Asian countries [45]. Furthermore, seaweeds are used as animal food, soil improver, and fertilizer. They are also used in the form of liquid extracts, as a growth regulatory and product protectors against pests and diseases [24]. The beneficial impacts of seaweed applications enhanced the capacity to improve the plant's growth yield along with stress resistance under salt conditions [19]. Seaweed extracts as biostimulants have not been wholly utilized due to lack of scientific data on growth factors present in seaweeds and their forms of action in affecting plant growth [27]. Seaweeds are applied as a foliar spray and enhance plant growth [34]. In addition to growth improving impacts of seaweed, there is growing evidence for a role of kelp in increasing plant tolerance to biotic stress such as infections and insects, and abiotic stress such as nutrition disorders, chlorinity, aridity and thermal stress [41].

As the goal of this study, we investigated the effects of salt stress on the build-up intensity of proline, the activities of antioxidant enzymes (SOD, POD, and CAT), the accumulation amount of lipid peroxidation (LPO), protein content, quantity of yield, fresh-dry weight in pepper plants. Thus, we hypothesized that application of salt at high dose could cause oxidative stress and hence adjust antioxidative defense system in pepper plants. Shortly, the primary goal of this paper was to obtain insight into the mechanisms by which humic acid and seaweed applications contribute to the preservation of plant against salt stress.

\section{MATERIAL AND METHODS}

\section{Plant growth conditions and treatments}

An entire design experiment was performed in triplicates in the field located at the Mugla Sitkı Koçman University, Turkey. A greenhouse pot investigation had been carried out from 02 March to 20 May 2015 with pepper plants (Capsicum annuum L. cv. Yalova Çarliston), which are assumed to be sensitive to salt stress based on the previous results. Three seedlings of the same size were planted into each pot filled with $20 \mathrm{~L}$ of a medium including peat and perlite in 1 to 3 ratio. After the adaptation to medium, the seedlings were thinned to sustain one per plastic pot. The plants were grown under controlled conditions at average $25^{\circ} \mathrm{C} / 18^{\circ} \mathrm{C}$ (day/night) temperatures. Plants were maintained for about 14 days before the beginning of salt stress $(100 \mathrm{mM}$ $\mathrm{NaCl}$ ) and other (SW and $\mathrm{HA}$ ) treatments. Water-soluble powder from the commer- 
Table 1

Pepper plants applied with varying levels of salt, seaweed, and humic acid

\begin{tabular}{|c|l|c|}
\hline Sample No. & \multicolumn{1}{|c|}{ Treatments } & Code name \\
\hline 1 & Control* & $\mathrm{C}$ \\
\hline 2 & Salt** & $\mathrm{S}$ \\
\hline 3 & Humic acid $\left(0.5 \mathrm{~g} \mathrm{~L}^{-1}\right)$ & HA1 \\
\hline 4 & Humic acid $\left(1 \mathrm{~g} \mathrm{~L}^{-1}\right)$ & HA2 \\
\hline 5 & Humic acid $\left(1.5 \mathrm{~g} \mathrm{~L}^{-1}\right)$ & HA3 \\
\hline 6 & Seaweed $\left(1 \mathrm{~g} \mathrm{~L}^{-1}\right)$ & SW1 \\
\hline 7 & Seaweed $\left(2 \mathrm{~g} \mathrm{~L}^{-1}\right)$ & SW2 \\
\hline 8 & Seaweed $\left(3 \mathrm{~g} \mathrm{~L}^{-1}\right)$ & SW3 \\
\hline 9 & Salt+Humic acid $\left(0.5 \mathrm{~g} \mathrm{~L}^{-1}\right)$ & SHA1 \\
\hline 10 & Salt+Humic acid $\left(1 \mathrm{~g} \mathrm{~L}^{-1}\right)$ & SHA2 \\
\hline 11 & Salt+Humic acid $\left(1.5 \mathrm{~g} \mathrm{~L}^{-1}\right)$ & SHA3 \\
\hline 12 & Salt+Seaweed $\left(1 \mathrm{~g} \mathrm{~L}^{-1}\right)$ & SSW1 \\
\hline 13 & Salt+Seaweed $\left(2 \mathrm{~g} \mathrm{~L}^{-1}\right)$ & SSW2 \\
\hline 14 & Salt+Seaweed $\left(3 \mathrm{~g} \mathrm{~L}^{-1}\right)$ & SSW3 \\
\hline
\end{tabular}

*Nutrient solution and irrigation water only.

**Salinity concentration as $(100 \mathrm{mM}) \mathrm{NaCl}$.

cial extract of $A$. nodosum (Pavoni \& C S.p.a.) (SW) was obtained from Kalender Group, Antalya, Turkey. Contents of seaweed: total organic matter $(30 \%)$, water soluble $\mathrm{K}_{2} \mathrm{O}(19 \%)$, alginic acid (8\%), and gibberellic acid (0.009\%). Humic acid prepared from leonardite was purchased from IZOTAR (Kemalpasa, İzmir/Turkey). Humic acid and seaweed extracts were applied to pepper plants with irrigation water. In SW and HA used experiments, five applications were made with 1-week intervals. The volume of the irrigation solution was 2 liters. For seaweed application, $100 \mathrm{~g}$ of raw material was dissolved in $100 \mathrm{~L}$ of water. Table 1 shows the $\mathrm{NaCl}$ and different amounts of other treatments with their code names.

The nutrient solution recommended by Hoagland and Arnon was used that contained: $\mathrm{P}\left(31 \mathrm{mg} \mathrm{L}^{-1}\right), \mathrm{N}\left(\mathrm{NO}_{3}\right.$-form) $\left(270 \mathrm{mg} \mathrm{L}^{-1}\right), \mathrm{Ca}\left(200 \mathrm{mg} \mathrm{L}^{-1}\right), \mathrm{K}\left(234 \mathrm{mg} \mathrm{L}^{-1}\right)$, $\mathrm{Mg}\left(48 \mathrm{mg} \mathrm{L}^{-1}\right), \mathrm{S}\left(64 \mathrm{mg} \mathrm{L}^{-1}\right), \mathrm{Mn}\left(0.5 \mathrm{mg} \mathrm{L}^{-1}\right), \mathrm{Fe}\left(2.8 \mathrm{mg} \mathrm{L}^{-1}\right), \mathrm{B}\left(0.5 \mathrm{mg} \mathrm{L}^{-1}\right)$, $\mathrm{Zn}\left(0.05 \mathrm{mg} \mathrm{L}^{-1}\right), \mathrm{Cu}\left(0.02 \mathrm{mg} \mathrm{L}^{-1}\right)$, and Mo $\left(0.01 \mathrm{mg} \mathrm{L}^{-1}\right)$. Nutrient medium's $\mathrm{pH}$ was adjusted to 6.5 with $\mathrm{KOH}(0.01 \mathrm{M})$. Throughout the whole growth period, plants were watered and provided with the indicated nutrients. The cultivated plants were harvested 75 days after seedling. For biochemical studies, 20 leaves were collected from each block separately. Leaf samples were taken from just below of the first leaf in the apical section (second leaf from the top). The leaves were stored in the refrigerator immediately after plucking until they arrive at the lab. Leaves were stored at $-20{ }^{\circ} \mathrm{C}$ in the lab freezer till further studies. 


\section{Lipid peroxidation levels}

Lipid peroxidation content was analyzed by determining the malondialdehyde (MDA) level by the method of Cakmak and Horst [10] with specific alterations just as recommended by Weisany et al. [40].

\section{Proline content}

Leaf free proline content was determined by the procedure developed by Bates et al. [6].

\section{Activities of antioxidant enzymes}

Fresh leaf material $(500 \mathrm{mg}$ ) was well grounded in sodium phosphate buffer (50 $\mathrm{mM}$ ), which contained $1 \%$ soluble polyvinyl pyrrolidone. Superoxide dismutase (SOD) was determined according to Giannopolitis and Ries [21], and Cakmak et al. [11]. Catalase activity (CAT) was established by the procedure of Bergmeyer [8]. Ascorbate peroxidase activity was determined by the Nakano and Asada [32] method. The POD was performed according to Herzog and Fahimi [25]. The Bradford [9] protocol was employed to estimate total soluble proteins.

\section{Yield analysis}

Pepper fruit production was analyzed on weekly bases $(\mathrm{kg})$ from the beginning of the fruit giving to the end of the harvest.

\section{Statistical analysis}

The obtained data were subjected to SPSS (v. 22) to work out variance analysis. Significant differences among mean values were assessed at $\mathrm{p} \leq 5 \%$.

\section{RESULTS}

\section{Dry matter and total product yield}

Exposure of pepper plants to salt stress $(100 \mathrm{mM})$ during the vegetative stage resulted in a general reduction in the plant growth. Analysis results shown in Figure 1 indicates that treatment of salt caused a decrease in the amount of leaf dry-weight and crop yield significantly, where the percentages of decline are nearly $17 \%$ and $24 \%$ 


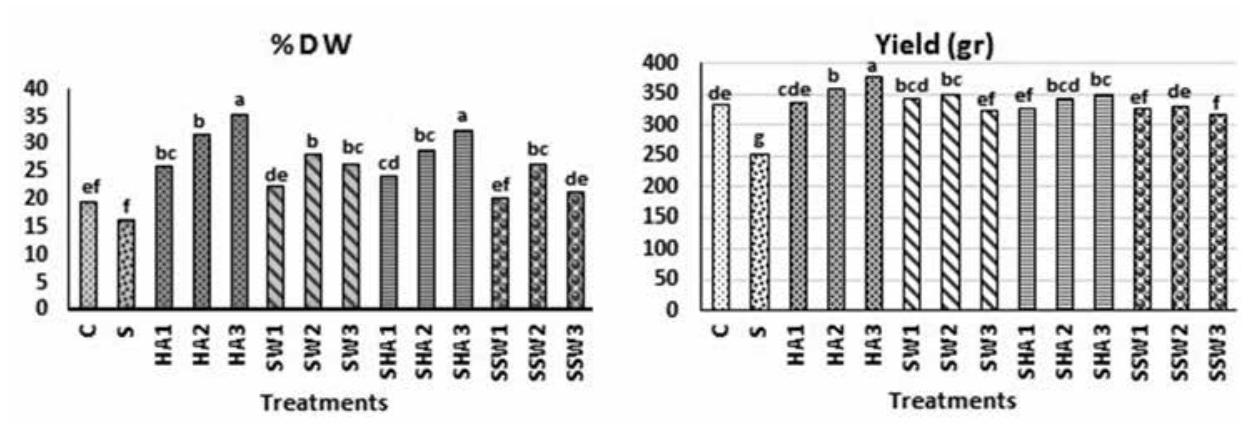

Fig. 1. The effects of HA and SW treatments on dry matter and total production yield of pepper plants grown in salt conditions. Different letters are significantly different $(\mathrm{P} \leq 0.05)$

relative to the control, respectively. However, these parameters increase with all treatments of both HA and SW. These increases are highest in pepper plants applied with high concentration of HA for both dry matter and product yield $\left(1.5 \mathrm{~g} \mathrm{~L}^{-1}\right)$. Besides, the combined treatments of salinity with HA or SW resulted in a significant recovery from the detrimental effects of salinity stress where dry leaf matter and crop yield were increased in comparison with the single treatment of salt stress, the values were also found higher than those of the control (Fig. 1).

\section{Leaf free proline content}

HA and SW treatments caused a decrease in salt caused an increased in proline amounts of $C$. annuum leaves. Third treatment of humic acid (HA3) induced the highest reduction in proline amount $\left(44.82 \mathrm{nmol} \mathrm{g}^{-1}, \mathrm{FW}\right)$ while the highest increase was observed in salt treatment (S) (109.02 $\left.\mathrm{nmol} \mathrm{g}{ }^{-1}, \mathrm{FW}\right)$ as compared to control (66.29 nmol g-1, FW) (Fig. 2).

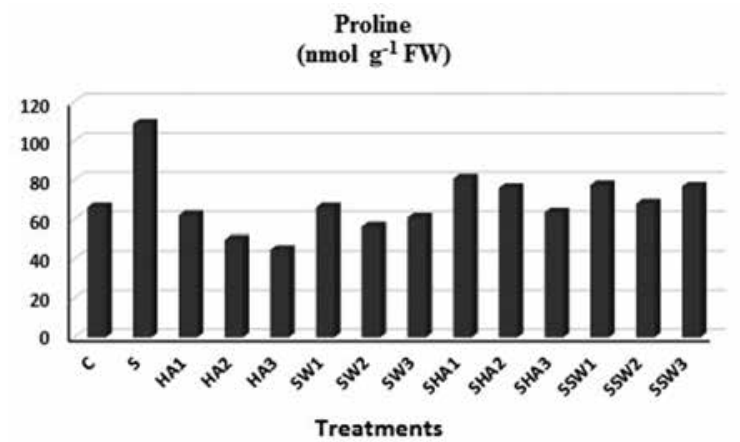

Fig. 2. The effects of humic acid and seaweed on proline content of pepper plants grown at salt conditions 


\section{Enzyme activities and lipid peroxidation}

Salt treatments resulted in increased activities of enzymes stated above and increased MDA levels. However, in all cases treatment of mentioned substances reduced those enzyme activities and MDA levels. Among the tested antioxidative enzymes, highest SOD amount was found in plants treated with salt, i.e., 46.25 unit $\mathrm{SOD} / \mathrm{mg}$ protein while HA3 treatment caused the highest decrease in the SOD amount, i.e., 11.84 unit $\mathrm{SOD} / \mathrm{mg}$ protein (control: 26.73 unit $\mathrm{SOD} / \mathrm{mg}$ protein). Statistically, a similar situation is also observed in other enzymes such as POD and CAT. Highest MDA levels were found in salt $\left(9.04 \mathrm{nmol} \mathrm{g}^{-1}, \mathrm{FW}\right)$ treated plants while the least amounts of MDA $\left(1.03 \mathrm{nmol} \mathrm{g}{ }^{-1}, \mathrm{FW}\right)$ were observed in SW3 as compared to the control (3.93 nmol $\left.\mathrm{g}^{-1}, \mathrm{FW}\right)$. There are various enzymes in plants that can increase or decrease during the stress conditions (Table 2).

Table 2

The effects of humic acid and seaweed on superoxide dismutase (SOD: unit mg protein ${ }^{-1}$ ), peroxidase (POD: unit protein ${ }^{-1}$ ), catalase (CAT: unit protein ${ }^{-1}$ ) and malondialdehyde (MDA: nmol g $\mathrm{g}^{-1} \mathrm{FW}$ ) levels of pepper plants grown at salty conditions

\begin{tabular}{|l|c|c|c|c|}
\hline Treatments & SOD & POD & CAT & MDA \\
\hline C & $26.73 \mathrm{def}$ & $26.85 \mathrm{~cd}$ & $14.02 \mathrm{f}$ & $3.93 \mathrm{fg}$ \\
\hline S & $46.25 \mathrm{a}$ & $54.48 \mathrm{a}$ & $25.22 \mathrm{a}$ & $9.04 \mathrm{a}$ \\
\hline HA 1 & $29.94 \mathrm{~cd}$ & $19.58 \mathrm{e}$ & $12.59 \mathrm{~g}$ & $3.81 \mathrm{~g}$ \\
\hline HA 2 & $22.36 \mathrm{fgh}$ & $12.27 \mathrm{~g}$ & $10.23 \mathrm{i}$ & $1.02 \mathrm{~h}$ \\
\hline HA 3 & $11.84 \mathrm{i}$ & $6.62 \mathrm{~h}$ & $8.87 \mathrm{j}$ & $1.13 \mathrm{~h}$ \\
\hline SW 1 & $28.21 \mathrm{de}$ & $20.17 \mathrm{e}$ & $12.67 \mathrm{~g}$ & $4.58 \mathrm{e}$ \\
\hline SW 2 & $18.66 \mathrm{~h}$ & $12.06 \mathrm{~g}$ & $9.45 \mathrm{j}$ & $1.39 \mathrm{~h}$ \\
\hline SW 3 & $21.26 \mathrm{gh}$ & $15.97 \mathrm{f}$ & $11.72 \mathrm{~h}$ & $1.03 \mathrm{~h}$ \\
\hline SHA 1 & $40.21 \mathrm{~b}$ & $36.84 \mathrm{~b}$ & $22.15 \mathrm{~b}$ & $6.89 \mathrm{c}$ \\
\hline SHA 2 & $33.77 \mathrm{c}$ & $20.85 \mathrm{e}$ & $16.63 \mathrm{~d}$ & $6.08 \mathrm{~d}$ \\
\hline SHA 3 & $18.55 \mathrm{~h}$ & $13.89 \mathrm{fg}$ & $12.13 \mathrm{gh}$ & $4.33 \mathrm{f}$ \\
\hline SSW 1 & $29.28 \mathrm{cde}$ & $28.25 \mathrm{c}$ & $19.53 \mathrm{c}$ & $7.45 \mathrm{~b}$ \\
\hline SSW 2 & $28.29 \mathrm{de}$ & $25.16 \mathrm{~d}$ & $15.14 \mathrm{e}$ & $6.79 \mathrm{c}$ \\
\hline SSW 3 & $25.00 \mathrm{efg}$ & $25.24 \mathrm{~d}$ & $15.47 \mathrm{e}$ & $7.42 \mathrm{~b}$ \\
\hline p $\leq 0.05$ & $*$ & $*$ & $*$ & $*$ \\
\hline F test & 34,745 & 190,009 & 330,420 & 262,336 \\
\hline
\end{tabular}

Note: values followed by different letters, in the same column, are significantly different at $\mathrm{P} \leq 0.05$ based on F-test. $* \mathrm{P} \leq 0.05$ 


\section{DISCUSSION}

Salinity has a direct effect on osmotic potential in natural and agricultural habitats. Additionally, saltiness affects various reactions going from growth inhibition and synthesis of some compounds to increase the osmotic capability of the cell and hence permits metabolic procedures to proceed by improving some antioxidant enzyme activities [31]. Various research studies have indicated the beneficial impact of seaweed extracts in promoting the growth of plants [5], and also humic acid treatments improve the productivity of soil because it enhances the number of soil micro-organisms and lowers the $\mathrm{pH}$ value of the soil [33]. Moreover, it is not surprising that most reported beneficial effects of HA on plant growth appear to be related to their positive influence on changes in the root system. Vegetation, with its associated microbial community, promotes the alteration of soil inorganic components and consequently directly influences soil solution chemistry [12]. SW extracts used as fertilizers could also improve plant productivity due to its containing growth promoting hormones [39]. Also, plants intakes nutrients either through roots or from the leaf surface. Seaweed extracts alter physical, biochemical and biological properties of the soil and may also affect the architecture of plant roots facilitating efficient uptake of nutrients [7]. This experiment intended to study the impact of salt stress and presence of HA and $\mathrm{SW}$ alone or as combinations, in recovering the hazardous effects of $\mathrm{NaCl}$ on growth, the activities of some antioxidative enzymes, the accumulation content of lipid peroxidation (LPO), protein content, proline levels, total yield, the percentage of dry weight on Capsicum annuum L.

In this study, treatment of salt led to an significant decrease in the leaf dry matter ratio and crop yield. But, it has been found that HA and SW have increased both solely and in combination with salt (Fig. 1). High- or low-salinity shock has been reported to affect photosynthetic rates of $S$. thunbergii sproutings importantly after exposure to adverse saltiness conditions for six $\mathrm{h}$ [30]. Our results overlap with the data of Latique et al. [28] found that salt stress decreased the dry weight of wheat plants compared to the control. However, the application of seaweed extract enhanced dry matter content in plants significantly. Similarly, seaweed essences have indicated satisfying conclusions as growth-yield-recommending factors in tropical trees [26]. The mechanisms by which Ascophyllum nodosum affects the growth of plants appear to be connected with the impacts of oligosaccharides, hormone-like elicitors, betaines, minerals that promote cell division and protein synthesis, and compounds that recover stress resistance [17]. Arthur et al. [1] also found an increase in growth and crop yield when seaweed Ecklonia maxima were applied to pepper (Capsicum annuит) plants. Applications of seaweed extracts derived from Kappaphycus alvarezii and Gracilaria edulis have been reported to increase the growth and yield of wheat [37]. Applying seaweed extracts have increased the yield of Phaseolus radiate L. These results are similar to those of Rathore et al. [35] in which application of seaweed extract (Kappaphycus alvarezii) increased growth significantly, yield and nutrient uptake in soybean plants. 
Proline seems to occur typically in advanced plants and usually accumulates in vast amounts as opposed to environmental stress [3]. Proline is known as an osmoprotectant [39] and is also usually promoted by salt in different species [22]. In addition to being an osmolyte, proline offers enzyme preservation and enhances tissue layer stability [23]. Generally, an increase in the pepper seedlings grown under salt stress as for proline content was detected, but HA or SW, both solely and combination with salinity, resulted in a significant decrease (Fig. 2). A reduce in proline amounts in comparison with the control group was noted earlier by Farahat et al. [18] during a study of exogenic treatments of humic acid on Khaya senegalensis seedlings. Similarly, Chbania et al. [13] suggested that the sunflower plants grown in medium with green alga Ulva lactuca resulted with low stress contrasted with those produced in control. Our results are indirectly proportional with those of the literature. The reason for this is that Ulva lactuca grows naturally in salinity conditions. It is a species with a high tolerance to salt, and it is thought that the salt in the structure is not entirely removed. It is this tendency that the proline levels of sunflower plant leaves are obtained higher than the control.

The highest activity levels of SOD, POD, and CAT in the leaves of pepper plants were found for salt stress solely, followed by combination with HA1 treatment, that is, it was obtained with the SHA1 application (Table 2). However, except for S and SHA1, it was determined that the antioxidative enzyme activities of pepper plant leaves decreased in all forms which were per the data of Gharib et al. [20] for rosemary plants. Similar results were also obtained for SOD, CAT, POD, and MDA by Y1ldiztekin et al. [42] while studying tomato plants. Latique et al. [28] suggest that seaweed extract enhances the tolerance of salt stress by activating the antioxidative enzyme system of superoxide dismutase, Catalase and by increasing the total phenolic matter which contributes to the protection of plants against oxidative harm to plant cell catalyzed by ROS. Lastly, the present results indicated that salt applications caused an increase in MDA content in the salt applied pepper plants (Table 2) which could be referred to peroxidation of membrane lipids that might be observed as enhanced MDA levels. Our findings show that decreased antioxidative enzyme activities and MDA contents due to SW and/or HA treatments may have ameliorated the physiological situation of pepper plants comprehensively. Similarly, salt stress affected plant nutrient, antioxidative enzyme activities, and it stimulates pressure that HA- or PGPR-applied plants usually asserted lower $\mathrm{H}_{2} \mathrm{O}_{2}$ and MDA levels than the comparable non-treated ones, signing lower gathering of ROS [16].

This study covers the dry matter, crop yield, lipid peroxidation, proline, proteins analyses and antioxidative (SOD, CAT, POD) enzyme activities treated with saline (NaCl-100 mM) and different concentrations of humic acid and seaweed (Ascophyllum nodosum) to Capsicum annuum (L.). Therefore, the treatments of SW and HA could be utilized as biostimulant in rehabilitation of land which can raise crop yield both in arable areas and in arid soil afflicted with salinity. 


\section{REFERENCES}

1. Arthur, G. D., Stirk, W. A., Van Staden, J. (2003) Effect of a seaweed concentrate on the growth and yield of three varieties of Capsicum annuum. S. Afr. J. Chem. 69, 207-211.

2. Ashraf, M., Harris, P. J. C. (2004) Potential biochemical indicators of salinity tolerance in plants Plant Sci. 166, 3-16.

3. Ashraf, M., Foolad, M. R. (2007) Roles of glycine betaine and proline in improving plant abiotic stress resistance. Environ. Exper. Bot. 59, 206-216.

4. Ashrafuzzaman, M., Khan, M. A. H., Shahidullah, S. M. (2003) Response of vegetative growth of maize (Zea mays) to a range of salinity. J. Biol. Sci. 3, 253-258.

5. Aymen, E. M., Salma, L., Halima, C., Cherif, H., Mimoun. E. (2014) Effect of seaweed extract of Sargassum vulgare on germination behavior of two tomatoes cultivars (Solanum Lycopersicum L.) under salt stress. Oct. Jour. Env. Res. 2, 203-210.

6. Bates, L. S., Waldren, R. P., Teare, I. D. (1973) Rapid determination of free proline for water stress studies. Plant Soil 39, 205-207.

7. Battacharyya, D., Babgohari, M. Z., Rathor, P., Prithiviraj, B. (2015) Seaweed extracts as biostimulants in horticulture. Sci. Hortic. 196, 39-48.

8. Bergmeyer, N. (1970) Methoden Der Enzymatischen Analyse. Berlin: Akademie Verlag, 1: pp 636-647.

9. Bradford, M. M. (1976) A rapid and sensitive method for the quantitation of micrograms quantities of protein utilizing the principle of Protein-Dye Binding. Anal. Biochem. 72, 248-254.

10. Cakmak, I., Horst, W. J. (1991) Effect of aluminum on lipid peroxidation, superoxide dismutase, catalase, and peroxidase activities in root tips of soybean (Glycine max). Physiol. Plant. 83, 463-468

11. Cakmak, I., Strbac, D., Marschner, H. (1993) Activities of hydrogen peroxide-scavenging enzymes in germinating wheat seeds. J. Exp. Bot. 44, 127-132.

12. Canellas, L. P., Olivares, F. L., Aguiar, N. O., Jones, D. L., Nebbioso, A., Mazzei, P., Piccolo, A. (2015) Humic and fulvic acids as biostimulants in horticulture. Sci. Hortic. 196, 15-27.

13. Chbania, A., Majed, S., Mawlawi, H., Kammoun, M. (2015) The use of seaweed as a bio-fertilizer: Does it influence proline and chlorophyll concentration in plants treated? AJMAP 1, 67-77.

14. Chen, Y., Aviad, T. (1990) Effects of humic substances on plant growth. In: MacCarthy, P., Clapp, C. E., Malcolm, R. L., Bloom, P. R. (eds), Humic Substances in Soil and Crop Sciences: Selected Readings. SSSA, Madison, pp. 161-186.

15. Clapp, C. E., Liu, R., Cline, V. W., Chen, Y., Hayes, M. H. B. (1998) Humic substances for enhancing turfgrass growth. In: Davies, G., Gabbour, E. A. (eds) Humic substances: Structures, properties, and uses. Royal Society of Chemistry Publ. Cambridge, U.K. pp. 227-234.

16. Esringü, A., Kaynar, D., Turan, M., Ercişli, S. (2016) Ameliorative effect of humic acid and plant growth-promoting rhizobacteria (PGPR) on Hungarian vetch plants under salinity stress. Commun. Soil Sci. Plant Anal. 47, 602-618.

17. Fan, D., Hodges, D. M., Critchley, A. T., Prithiviraj, B. (2013) A commercial extract of brown macroalga (Ascophyllum nodosum) affects yield and the nutritional quality of spinach in vitro. Commun. Soil Sci. Plant Anal. 44, 1873-1884.

18. Farahat, M. M., Mazhar, A. A., Mona, H., Mahgoub, M. H. (2012) Response of Khaya senegalensis seedlings to irrigation intervals and foliar application of humic acid. JHSOP 4, 292-298.

19. Fornes, F., Sánchez-Perales, M., Guadiola, J. L. (2002) Effect of a seaweed extract on the productivity of 'de Nules' Clementine mandarin and navelina orange. Bot. Mar. 45, 486-489.

20. Gharib, F. A. E. L., Zeid, İ. M., Salem, O. M. A. E. H., Ahmed, E. Z. (2014) Effects of Sargassum latifolium extract on growth, oil content and enzymatic activities of rosemary plants under salinity stress. Life Sci. 11, 933-945.

21. Giannopolitis, C. N., Ries, S. K. (1977) Superoxide dismutases occurrence in higher plants. Plant Physiol. 59, 309-314. 
22. Haddadi, B. S., Hassanpour, H., Niknam, V. (2016) Effect of salinity and waterlogging on growth, anatomical and antioxidative responses in Mentha aquatica L. Acta Physiol. Plant 38, 119.

23. Hayat, S., Hayat, Q., Alyemeni, M. N., Wani, A. S., Pichtel, J., Ahmad, A. (2012) Role of proline under changing environments: a review. Plant Signal. Behav. 7, 1456-1466.

24. Henderson, J. (2004) The Roman book of gardening. Routledge, London.

25. Herzog V., Fahimi, H. (1973) Determination of the activity of peroxidase. Anal. Biochem. 55, $554-562$.

26. Karthikeyan, K., Shanmugam, M. (2014) Enhanced yield and quality in some banana varieties applied with commercially manufactured biostimulant Aquasap from sea plant Kappaphycus alvarezii. J. Agr. Sci. Tech. B 4, 621-631.

27. Khan, W., Rayirath, U. P., Subramanian, S., Jithesh, M. N., Rayorath, P., Hodges, D. M., Critchley, A. T., Craigie, J. S., Norrie, J., Prithiviraj, B. (2009) Seaweed extracts as biostimulants of plant growth and development. J. Plant Growth Regul. 28, 386-399.

28. Latique, S., Chernane, H., Mansori, M., El Kaoua, M. (2016) Biochemical modification and changes in antioxidant enzymes in Triticum durum L. by seaweed liquid extract of Ulva rigida macroalgae under salt stress condition. Adv. Environ. Res. 50, 35-54.

29. Li, W., Liu, X., Khan, M. A., Yamagnchi, S. (2005) The effect of plant growth regulators, nitric oxide, nitrate, nitrite and light on the germination of dimorphic seeds of Suaeda salsa under saline conditions. J. Plant Res. 118, 207-214.

30. Liang, Z., Sun, X., Wang, F., Wang, W., Liu, F. (2013) Impact of environmental factors on the photosynthesis and respiration of young seedlings of Sargassum thunbergii (Sargassaceae, Phaeophyta). Am. J. Plant Sci. 4, 27-33.

31. Manaf, H. H. (2016) Beneficial effects of exogenous selenium, glycine betaine and seaweed extract on salt stressed cowpea plant. Ann. Agric. Sci. 61, 41-48.

32. Nakano, Y., Asada, Y. (1987) Purification of ascorbate peroxidase from spinach chloroplasts: Its inactivation in ascorbate depleted medium and reactivation by monodehydroascorbate radical. Plant Cell Physiol. 28, 131-140.

33. Osman, A. S., Rady, M. M. (2012) Ameliorative effects of sulfur and humic acid on the growth, antioxidant levels, and yields of pea (Pisum sativum L.) plants grown in reclaimed saline soil. J. Hortic. Sci. Biotechnol. 87, 626-632.

34. Popescu, G. C., Popescu, M. (2014) Effect of the brown alga Ascophyllum nodosum as biofertilizer on vegetative growth in grapevine (Vitis vinifera L.). CTNS 3, 61-67.

35. Rathore, S. S., Chaudhary, D. R., Boricha, G. N., Ghosh, A., Bhatt, B. P., Zodape, S. T., Patolia, J. S (2009) Effect of seaweed extract on the growth, yield and nutrient uptake of soybean (Glycine max) under rainfed conditions. S. Afr. J. Bot. 75, 351-355.

36. Shah, M. T., Zodape, S. T., Chaudhary, D. R., Eswaran, K., Chikara, J. (2013) Seaweed sap as an alternative liquid fertilizer for yield and quality improvement of wheat. J. Plant Nutr. 36, 192-200

37. Sylvia, S., Baluswami, M., Parthasarathy, V. M. D., Krishnamurthy, V. (2005) Effect of liquid seaweed fertilizers extracted from Gracilaria edulis (Gmel.) Silva, Sargassum wightii greville and Ulva lactuca Linn. on the growth and yield of Abelmoschus esculentus (L.) Moench. Indian Hydrobiol. 7, 69-88.

38. Temple, W. D., Bomke, A. A. (1989) Effects of kelp (Macrocystis integrifolia and Ecklonia maxima) foliar application on bean crop growth. Plant Soil 117, 85-92.

39. Wang, Y., Xiang, L., Wang, S., Wang, X., Chen, X., Mao, Z. (2017) Effects of seaweed fertilizer on the Malus hupehensis Rehd. seedlings growth and soil microbial numbers under continuous cropping. Acta EcoL. Sin. 37, 180-186.

40. Weisany, W., Sohrabi, Y., Heidari, G., Siosemardeh, A., Golezani, K. G. (2012) Changes in antioxidant enzymes activity and plant performance by salinity stress and zinc application in soybean (Glycine max L.). Plant Omics. 5, 60-67.

41. Xu, C., Leskovar, D. I. (2015) Effects of Ascophyllum nodosum seaweed extracts on spinach growth, physiology and nutrition value under drought stress. Sci. Hort. 183, 39-47. 
42. Y1ldiztekin, M., Kaya, C., Tuna, A. L., Ashraf, M. (2015) Oxidative stress and antioxidative mechanisms in tomato (Solanum lycopersicum L.) plants sprayed with different pesticides. Pak. J. Bot. 47, $717-721$.

43. Yildiz, M., Terzi, H. (2013) Effect of $\mathrm{NaCl}$ stress on chlorophyll biosynthesis, proline, lipid peroxidation and antioxidative enzymes in leaves of salt-tolerant and salt-sensitive barley cultivars. JAS 19, 79-88

44. Zodape, S. T., Mukhopadhyay, S., Eswaran, K., Reddy, M. P., Chikara, J. (2010) Enhanced yield, and nutritional quality in green gram (Phaseolus radiata $\mathrm{L}$ ) treated with seaweed (Kappaphycus alvarezii) extract. JSIR 69, 468-471.

45. Zou, X. X., Xing, S. S., Su, X., Zhu, J., Huang, H. Q., Bao, S. X. (2017) The effects of temperature, salinity, and irradiance upon the growth of Sargassum polycystum C. Agardh (Phaeophyceae). J. Appl. Phycol. 29, 1-9. 